\title{
Influencing Factors of the United States Renegotiation of the North American Free Trade Agreement (NAFTA) under the Trump Administration
}

\author{
Nisrina Nur Aathif ${ }^{1}$
}

\author{
${ }^{1}$ Universitas Indonesia \\ ${ }^{*}$ Corresponding author. Email: nisrina.nuraathif@ui.ac.id
}

\begin{abstract}
Abstract - The United States (US) joined North American Free Trade Agreement (NAFTA) trade regime along with Canada and Mexico to increase trade among members by reducing or eliminating trade restrictions such as tariffs and import quotas. Under the Trump administration, the United States - for the first time-proposed changes to NAFTA and stated it would leave NAFTA if the proposed changes were rejected. This research attempts to elaborate on the factors that influenced US renegotiation of NAFTA, which had been implemented since 23 years. The realist and liberalist approaches are insufficient to explain such behavior because insufficient attention is paid to the role of ideas and social construction. Therefore, the theory used to answer the research question is the international regime theory: a weak cognitivist approach that considers that state behavior in a regime's order is generally based on the ideas and knowledge possessed by the state, the learning process, and the role of epistemic communities.
\end{abstract}

Keywords: International Regimes, NAFTA, State Behavior, Weak Cognitivist, Ideas and Knowledge, The Process of Learning, Epistemic Communities

\section{INTRODUCTION}

In anarchical world politics, common rules or norms that regulate actions on a topic are shaped by states because of rational behavior (Keohane, 1982). The collection of common rules or norms regarding an issue is called an international regime. International regimes emerge and exist in various fields in contemporary world politics, such as security, the environment, and economics. One of the many forms of international regimes in economics is the North American Free Trade Agreement (NAFTA), a joint commitment to regulate economics, namely, free trade among the North American countries: the United States (US), Canada, and Mexico.

The impetus for NAFTA was an eagerness to open a bilateral free trade route between Canada and the US and between Mexico and the US. In 1991, NAFTA negotiations were initiated by US President George HW Bush, Prime Minister of Canada Brian Mulroney, and the President of Mexico Carlos Salinas de Gortari (Payne, 2017). NAFTA was ratified by the respective national legislatures in 1993 and implemented on January 1, 1994 (Payne, 2017).
The purpose of NAFTA was to increase the economic growth of member countries. The main objectives were to reduce barriers or trade tariffs promote fair trade competition, increase investment opportunities, and protect the intellectual property rights of member countries (Payne, 2017). The purpose of the provision to open a free market was to gradually eliminate all tariffs and non-tariff barriers on produced and traded goods between member countries for the next 15 years.

The United States, under President Bush and President Barak Obama, demonstrated its compliance with NAFTA. Although the dynamics of NAFTA have advantages and disadvantages, this trade regime has been used as an option for the US economic sector. Generally, NAFTA provides at least six benefits to member countries: multiple trade, low prices, economic growth, job opportunities, increased foreign direct investment, and government spending reduction (CFR, 2017).

States tend to obey a regime they have agreed to but may not when their obedience to the regime undergoes significant changes. A state can change its behavior and policies to change the regime. Additionally, a state could 
violate and neglect the regime, a situation that has occurred under US President Donald Trump, despite its benefits from NAFTA.

During the Trump administration, the United States has issued a trade protection policy for NAFTA members that is clearly at odds with the previous NAFTA agreement. President Trump stated that he would withdraw from NAFTA if the agreement was not amended according to his proposals. President Trump was elected in 2017 , despite losing the popular vote by approximately 3 million votes. Since the start of his election campaign, President Trump has promoted his "America First" policy to supposedly improve US progress in various fields and prioritize domestic interests and profits.

The author further examines the influencing factors that changed US behavior under President Trump, because before this administration, the United States had always obeyed and supported NAFTA. Through the explanation of this topic, the following research question arose: What factors influenced and United States to renegotiate NAFTA, despite its 23 years of benefits for member countries?

International relations theory is used to answer this question, that is, this study attempts to explain the changes in US ideas about and knowledge of NAFTA, the learning process of the United States during NAFTA, and the role of epistemic communities in the renegotiation of NAFTA.

The author proposes that idea-based or knowledgebased approaches in international relations must be used to understand changes in state behavior. Considering that national interest is constructed by ideas and social processes could provide a more comprehensive analysis of states and international regimes. In other words, realism and liberalism, which argue that interests and policies are exogenously provided, must be supplemented or supplanted by an approach that focuses on the distribution of ideas and knowledge.

Regime-based researchers have generally analyzed the explanation of how regimes emerge in international systems, what variables determine the success of regimes, and what factors affect the behavior of actors toward regimes, which could be from domestic or international systems. Therefore, the author analyzes this topic by applying the knowledge-based perspective of international regime theory with a weak cognitivist approach. In this perspective, state behavior in an international regime is determined by three elements: ideas and knowledge, the learning process, and the role of epistemic communities.

This research is significant for international relations because knowledge-based international regime theory is applied to analyze state behavior, and this method has rarely been used in international relations literature. By raising contemporary issues in international relations, this research is empirically significant. For Indonesia, this research is significant because the nation also has a regional trade regime: ASEAN Free Trade Area. Therefore, this paper is a reference for Indonesia when managing changes in behavior among its members. Notably, Indonesia has close bilateral relations with the United States, which could be affected by the policies of President Trump.

\section{THEORETICAL PERSPECTIVE}

\subsection{International Regime Theory}

Various dimensions of international regimes remain topics of debate. The development of and changes in international regimes have resulted in imprecise and inappropriate definitions. In general, an international regime comprises an agreement on norms, rules, and procedures for policy-making on a specific topic, and the actors involved have agreed to accept and comply with them (Krasner, 1983).

International regime theory provides approaches to understand state behavior in the context of international regime order. These approaches can analyze factors that influenced the United States to renegotiate NAFTA. This research approach (i.e., international regime theory in the cognitivist school of thought with weak cognitivist approach) assumes that state behavior in an international regime considers the ideas and knowledge of the state, the learning process of the state in the regime, and the role of the epistemic community. These three considerations are used to answer the research question.

An international regime can emerge when the behavior is shaped by state leaders to facilitate the resolution of common problems in international relations (Rowlands, 1991). In other words, an international regime can occur as a reaction when coordinating the behavior of various states and/or other related actors on a particular subject is necessary. By forming or following an international regime, the state binds itself to general standards of behavior without disregarding the juridical sovereignty of each country, leads to the emergence of a new dimension of interstate connections. This dimension is closely related to the state functional role as a manifestation of the global order (Hasenclever, Mayer and Rittberger, 1997).

Generally, three schools of thought or paradigms have become the basis for the discussions on international regimes: realism that focuses on power relationship, liberalism that bases its analyzes on constellations of interest, and cognitivism that emphasizes knowledge dynamics. These schools of thought also have distinct views on the degree of robustness of international institutions, measured by 
states' conformity with norms or rules within particular regime. According to Hasenclever, Mayer and Rittberger (1997), as a power-based perspective, realism only stresses how relative power creates obstacles for international cooperation. As a result of an anarchical environment in which states struggle for survival and independence, states are rational-egoist actors that only care for their own gain (relative gain). Compared with Realism, as an interest-based perspective, neoliberalism emphasizes the role of international regimes in helping states realize common interests. States are rational-egoist actors who care only for their own gain (absolute gain). The third perspective is cognitivism, which this research discusses further by focusing on knowledge as determiner of states' interests. Instead, of using rationalistic perspectives, the author uses sociological approach to understand and decisions of states. Hence, states are better understood as role-players than as utility-maximizers.

Table 1. Schools of Thought in International Rgimes (Hasenclever, Mayer and Rittberger (1997)

\begin{tabular}{|l|l|l|l|}
\hline \multirow{2}{*}{} & \multicolumn{2}{|l|}{ School of Thought } & \multicolumn{2}{l|}{ Nognitivism } \\
\cline { 2 - 4 } & Realism & $\begin{array}{l}\text { Neoliberalis } \\
\text { (especially } \\
\text { strong } \\
\text { cognitivism) }\end{array}$ \\
\hline $\begin{array}{l}\text { Main } \\
\text { Variable }\end{array}$ & Power & Interest & Knowledge \\
\hline $\begin{array}{l}\text { "Institutional } \\
\text { ism" }\end{array}$ & Weak & Medium & Strong \\
\hline $\begin{array}{l}\text { Meta- } \\
\text { theoretical } \\
\text { orientation }\end{array}$ & $\begin{array}{l}\text { Rationalis } \\
\text { tic }\end{array}$ & Rationalistic & Sociological \\
\hline $\begin{array}{l}\text { Behavioral } \\
\text { Model }\end{array}$ & $\begin{array}{l}\text { Concerne } \\
\text { d with } \\
\text { relative } \\
\text { gains }\end{array}$ & $\begin{array}{l}\text { Absolute } \\
\text { gains } \\
\text { maximizer }\end{array}$ & Role-player \\
\hline
\end{tabular}

\subsection{Knowledge-Based Regime Theory/Cognitivist}

Knowledge-based regime theory is a criticism of the rationalist approach. Liberalists and realists treat states' identities and interests in an international regime as exogenously given. The basic assumption of knowledgebased theory is that an international regime emerges because of the dissatisfaction with the dominant concepts of international rules, authority, and organization. Therefore, it must return to knowledge. This knowledgebased approach is also called the cognitivist approach, which uses ideas and knowledge as the main variables and emphasizes the forming process of self- understanding of a state (e.g., understanding of one's identity) and the goals of a state to be achieved through its foreign policy. This process is influenced by normative and causal beliefs (beliefs concerning causes and effects of things) held by policymakers. Therefore, changes in the belief system of a state are believed to trigger policy changes (Hasenclever, Mayer and Rittberger, 1997).

Knowledge-based theory uses two approaches: weak cognitivism, where states are considered rational actors, and strong cognitivism, where states are considered social actors. Therefore, weak cognitivism emphasizes the origins and dynamics of the understanding of rational actors, whereas strong cognitivism emphasizes the origins and dynamics of understanding of social actors (Hasenclever, Mayer and Rittberger, 1997).

\subsection{Weak Cognitivism}

Weak cognitivism attempts to complement realism and neoliberalism theories through its focus on the emergence of communities related to knowledge (Hasenclever, Mayer and Rittberger, 1997). For the weak cognitivist, foreign policy depends on state identity and their supposed interests in international relations. These two factors are stimulated by the ideals and beliefs embraced by policymakers. These ideals and beliefs then determine the cognitivist's basic assumptions, that is, by maximizing states' rationality and interests, they are influenced by their perceptions of what they want to achieve as interests, even though these interests can change because of knowledge. (Hasenclever, Mayer and Rittberger, 1997). Weak cognitivism has three main assumptions that underlie state behavior: the role of ideas and knowledge (e.g., individuals' causal and normative beliefs), the learning process, and the role of epistemic communities (Hasenclever, Mayer and Rittberger, 1997).

\subsubsection{The Role of Ideas and Knowledge}

What is between international structures and human desires had been interpreted. Before a choice to cooperate can be determined, the circumstances must be estimated, and the interests must be identified. Interpretation is defined as something dependent on the knowledge possessed by the actor at a specific time and place. This knowledge shapes the perception of reality and provides knowledge to the decision makers concerning causal relationships and objectives.

Ideas can relate to international regimes through two causal pathways, according to Goldstein and Keohane (1993). First, widely shared ideas may be focal points that help define acceptable solutions to collective action problems; related to this, Garrett and Weingast (1993) explain that in the absence of ideas as focal points, regimes often do not form. Second, the impact of ideas is 
often mediated and enhanced by norms and rules created under the influence of widely shared beliefs. Once ideas are embodied in institutional frameworks, they constrain public policy if not effectively undermined by scientific discoveries or normative change (Hasenclever, Mayer and Rittberger, 1997). To conclude, ideas play a more fundamental role in shaping the regime when institutions promote the ideas to be maintained.

Interest neither exists nor is "given." Interest is choices seen and treated analytically that depend on how the actor understands the natural and social world. Therefore, the knowledge possessed by actors projected in international meetings significantly shapes their behavior and expectations.

\subsubsection{Learning Process}

New information in the form of ideas, knowledge, or beliefs is accepted by an actor and can lead to behavioral responses. In addition, the changes in ideas, knowledge, and beliefs of an actor can induce behavioral changes. This process is a learning process attempts to understand how new knowledge influences state behavior to reconstruct the process of regime change. Nye (1987) divided this process into two forms: simple and the complex learning. Simple learning is the actor's new understanding of her or his social-political environment, which can encourage policymakers to change their policies to achieve goals that basically do not change. Complex learning is the redefining of national interests, including determining new, appropriate goals and strategies (Hasenclever, Mayer and Rittberger, 1997).

Complex learning is critical to cognitivism because states sometimes alter their strategies in a manner in line with their national interests. States learn by responding to structural changes in their environment, or in game theory terms, they adjust their behavior to changes in the pay-off matrix (Nye, 1987). This assumption is more likely to fit the behavior of the powers that control an international regime.

\subsubsection{Role of Epistemic Communities}

According to Krasner (1983), to affect regime formation, knowledge must be widely shared by policymakers. New knowledge must be disseminated by policymakers to impact decision-making. A group of scholars led by Peter Haas argued that epistemic communities are crucial channels where new ideas circulate from societies to governments and among countries (Haas, 1992).

Epistemic communities are a group of professionals recognized for their expertize and competence in a field that possess relevant knowledge of policies related to their field (Hasenclever, Mayer and Rittberger, 1997).
Epistemic communities influence the framing of collective debate. Basically, the members of such communities share an understanding and discuss how to solve problems in a regime. Epistemic communities tend to actively strive to convey or express their ideas rather than being passive or obedient to the decisions of policymakers.

Four phases of epistemic communities' influence policy determination: policy innovation (the agents of policy innovation in epistemic communities may influence the framing of topics for collective debate), policy diffusion (through ideas shared with their transnational links, experts, and colleagues), policy determination (if they provide integrative formulas in complex negotiations), and policy sustainability (the well-established or authorized epistemic communities may operate as effective advocates to defend and strengthen the regime; Hasenclever, Mayer and Rittberger, 1997).

\section{INFLUENCING FACTORS OF THE UNITED STATES' RENEGOTIATION OF NAFTA UNDER PRESIDENT TRUMP}

This chapter is the author's elaboration on the influencing factors of the US renegotiation of NAFTA under President Trump. The author analyzes the factors in the context of the international regime theory framework by applying the weak cognitivism approach, which considers state behavior in the context of the international regime. This approach emphasizes that international regimes are influenced by ideas and knowledge possessed by the actor, learning processes, and the role of epistemic communities.

\subsection{Changes in US Ideas about and Knowledge of NAFTA}

This subchapter explains the changes in US ideas about and knowledge of NAFTA during the Trump administration that have influenced US behavior. In its dynamics, from the beginning of the conclusion of NAFTA to the end of the Obama administration, the United States has interpreted NAFTA as one of the choices for trade sector, despite the positive and negative impacts of its implementation. However, ideas and knowledge were maintained, and the policies issued never left the corridor of the NAFTA agreement. The changes occurred when the Trump administration began to interpret NAFTA as disadvantageous.

The weak cognitivist approach emphasizes the interpretation of the differences between international structure and human interests. Before conducting an action, the surroundings must be analyzed and the interests must be identified. Interpretation is created by knowledge possessed by an actor at a certain time and 
place. This knowledge creates a perception of reality and informs policymakers about causal relationships and objectives (Hasenclever, Mayer and Rittberger, 1997). The changes in ideas and knowledge possessed by a state cannot be separated from the ideas and knowledge possessed by its leader. These changes influence the policymakers' interpretation and perception of reality. The knowledge of the actors, which has been projected in international meetings, significantly shapes their behavior and expectations.

At the beginning of NAFTA, President Bill Clinton had a positive interpretation and perception that this trade regime would contribute to the economic development of the United States (Morrow and Curry, 2018). President Bush shared the same view: In a speech, he said that NAFTA had created millions of jobs and helped improve the economy of member countries (Frosch, 2016). Similarly, President Obama stated that despite its weakness, NAFTA was not a failure but an opportunity that requires corrections (Grunwald, 2017).

\subsubsection{NAFTA under President Bush}

The ideas and knowledge of President Bush toward free markets and NAFTA have been influenced by his experience in politics and business schools. Since 1978, he proposed that the United States should be governed by the conservative principles of that time, and not similar to the European welfare-state version, where the central government has limited independently owned companies (Bush, 2010). His experience during business school in China taught him that free markets supposedly provide the fairest means to allocate resources (Bush, 2010). Eliminating trade barriers means creating new export markets for domestic producers and more options for domestic consumers. According to President Bush, the government must respect its constitutional limits (Bush, 2010). This idea established President Bush's perception that free trade was a favorable policy for the United States.

With that perception, President Bush projected his knowledge in international meetings in the form of his full support for NAFTA, indicated by the high intensity of the meeting to discuss improvements to NAFTA. During his administration, Commission Meetings were implemented eight times, involving cabinet-level representatives who met once per year to supervise the implementation of NAFTA, to oversee the elaboration of further regulations, resolve disputes concerning the interpretation of agreement, and consider other matters that could influence its implementation (Foreign Trade Information System Organization of American States, 2018). The Working Group on the Rules of Origin meeting has been held 17 times, provides education on NAFTA regulations, was intended to propose technical improvements to the rule and modify the initial rule.
In addition to influencing behavior, the perception of President Bush concerning free trade and NAFTA was also influenced by his expectation that NAFTA would benefit the United States. In a dialogue with the Dallas News in 2015, President Bush stated that NAFTA was carried out successfully according to his expectations (Dallas News, 2015). NAFTA has become a win-win solution for member countries. This success was based on the number of trades, which were worth approximately US\$ 1.2 trillion between member countries (Dallas News, 2015).

\subsubsection{NAFTA under President Obama}

President Obama's ideas and knowledge of free trade were influenced by his service as a Democratic US Senator from Illinois. He directly observed how communities in small towns were destroyed when producers relocated abroad to reduce expenses by, for example, paying lower wages to workers in other countries for performing the same job. This experience established the idea and knowledge that the international trade regime requires strict standards that protect the equality and welfare of its workers. President Obama also proposed the idea and knowledge that expanding trade and breaking down the barriers between countries benefit the economy, security, consumers, and domestic workers (Talbott, 2008). Ideas and knowledge have established President Obama's perception, that is, the trade regime was profitable and should continue to consider the welfare of workers.

This perception successfully shaped President Obama's behavior. Consequently, NAFTA was the main concern of US trade policy. This phenomenon was not caused by the harmful effects of NAFTA on the US economy but because of its weak agreement on the welfare of workers and market coverage. President Obama focused more on larger free-market agreements, namely, the Trans-Pacific Partnership (TPP), which comprised 12 countries, including Canada and Mexico. Furthermore, the TPP has firm agreements on standards that guarantee workers' equality and prosperity and environmental protection. Although President Obama prioritized the TPP over NAFTA, the NAFTA Commission Meeting was held three times (i.e., 2009, 2011, and 2012) and the Working Group on Rules of Origin meeting was held three times.

\subsubsection{NAFTA under President Trump}

President Trump has a new interpretation and perception of NAFTA that differs from his predecessors, that is, NAFTA has adverse affected the United States. This perception was established based on his ideas and knowledge influenced by his experience as a businessman since 1971. According to President Trump, 
the best scheme to manage a country that of a for-profit enterprise; thus, every policy must benefit the United States over other countries (Trump, 2011). President Trump has inserted his ideas and knowledge into the stated direction of US foreign policy as follows,

"My foreign policy will always put the interests of the American people, and American security, above all else. America First will be the major and overriding theme of my administration. I want to identify five main weaknesses in our foreign policy: our resources are overextended, our allies are not paying their fair share, our friends are beginning to think they can't depend on us, our rivals no longer respect us, finally, America no longer has a clear understanding of our foreign policy goals (Trump, 2016)."

President Trump emphasized that "our allies are not paying their fair share as a number of parties" to show that parties are harmful to the United States, and one was NAFTA. President Trump stated that NAFTA was one of the worst agreements of any country and did not contribute to the economic development of the United States but did substantiate his opinion (Jagannathan, 2017).

The ideas and knowledge of President Trump have changed the perception of NAFTA. How President Trump then used this new idea and knowledge to reconstruct the change process of the NAFTA regime is explained through the learning process and consideration of the role of epistemic communities in subchapter B.

\subsection{Learning Process of the United States in NAFTA}

This subchapter explains the learning process of the United States in the implementation of NAFTA. The United States has followed NAFTA for more than 20 years. In the process, there have been positive and negative dynamics in its implementation. During the process, the United States conducted the learning process, namely, when new knowledge of a state leader or stakeholders is disseminated to the main policymakers until it is able to influence new policies.

As discussed, President Trump has disseminated new ideas and knowledge to the United States regarding the interpretation of NAFTA. The process of ideas and knowledge experienced by the United States changed, starting with President Bush, who fully supported NAFTA, to President Obama, who criticized the weak regulations to protect workers' welfare. Although he did not take any action against NAFTA, President Trump perceived and considered NAFTA an unfavorable regime and thought that changes to NAFTA must be realized.

A new understanding of the state toward its sociopolitical environment can influence decision makers to conduct two things. First, decision makers change the strategy to achieve the same or fixed goals. Second, decision makers redefine their interests and determine new goals and appropriate strategies. In this case, the ideas and knowledge of President Trump proposed a reconstruction according to new interests and goals of the US and appropriate strategies to renegotiate NAFTA.

Under President Trump, the United States redefined its interest in NAFTA related to the changes in understanding and knowledge that NAFTA was an ineffective and unprofitable regime. The new definition of US interests proposed by President Trump is "America First," which supposedly prioritizes national interest and profits for the US. After redefining its interest, this knowledge should be disseminated to implemented in a country's policy.

In President Trump's first attempt to negotiate new objectives of NAFTA, the target was to improve the trade balance and reduce the trade deficit with NAFTA countries in the renegotiation of NAFTA, although it is inappropriate to use a trade agreement clause as a tool to decrease the deficit. Trump and some officials said that trade deficits were harmful to the US economy. The proposed evidence was as follows: The fluctuation in the trade balance with NAFTA partners increased from $\$ 9.1$ billion in 1993 to $\$ 89.6$ billion in 2017 (Villarreal and Fergusson, 2018).

The renegotiation of NAFTA based on the directives of President Trump is the result of his awareness of the US fortune. He delivered this statement in his first official State of the Union Address on January 13, 2018, as follows:

"America has finally turned the page on decades of unfair trade deals that sacrificed our prosperity and shipped away our companies, our jobs, and our nation's wealth. From now on, we expect trading relationships to be fair and to be reciprocal. We will work to fix bad trade deals and negotiate new ones" (Breuninger, 2018).

President Trump declared his intention during his election campaign to withdraw from or renegotiate NAFTA if elected president (Villarreal and Fergusson, 2018). He highlighted his opinion that the trade deficit with NAFTA partners was the main problem (Villarreal and Fergusson, 2018). After becoming president, the Trump administration sent a 90-day notification to the US Congress regarding his intention to renegotiate NAFTA with Canada and Mexico on May 18, 2017, as required by the Trade Promotion Authority 2015 (Villarreal and Fergusson, 2018).

President Trump's new knowledge influenced the US Congress, the majority of which were members of his party, to approve his proposal to renegotiate NAFTA and rendered it part of US international trade policy. Official negotiations with NAFTA member countries began on August 16. Eight official rounds of negotiations occurred 
at the end of April 2018. In May, the negotiators from each member country continued a "permanent" round to discuss technical issues and to report notable issues such as US proposals concerning automotive rules, seasonal production, dispute resolution, sunset clauses to reevaluate agreements every five years, and other concerns such as labor and intellectual property rights (Villarreal and Fergusson, 2018). The ministers of trade from the United States, Canada, and Mexico stated their commitment to an "accelerated and comprehensive negotiation process that will enhance the agreement and set 21st century standards for the benefit of NAFTA member countries" (Villarreal and Fergusson, 2018).

\subsection{Role of Epistemic Communities under President Trump}

A policy can be agreed upon through considerations. One of many means is consideration of the analysis of epistemic communities. Epistemic communities are a network of professional experts with expertize and competencies recognized in a field and who possess relevant knowledge on related policies. Examples of epistemic communities are academic departments, a president's staff, and nongovernmental organizations. Under US policy, the epistemic communities that play a significant role are the people who staff the Trump administration and support his NAFTA renegotiation policy: US Trade Representatives Peter Navarro and Robert Lighthizer, and the Congressional Research Service (CRS).

Peter Navarro is a business school professor and a former member of the Peace Corps and Democratic Party. President Trump considered him a trusted trade advisor (Lowrey, 2018). Navarro's role is to redirect Trump's extreme ideas, turn the modified version into reality, and ensure that the president's knowledge and beliefs are not weakened despite officials' interpretation that they were negotiated. Navarro is the actor behind President Trump's "madman theory" of trade policy, that is, make enemies and allies believe that the president can and will do anything to make America "great" again (Lowrey, 2018).

Lighthizer is one of the actors that lobbied for congressional approval of the renegotiation NAFTA. Lighthizer proposed a strategy to obtain congressional support by forcing congressional agreements concerning the new NAFTA and withdrawing from the existing agreement before the new agreement was ready (Behsudi and Restuccia, 2018). Another reason used to force Congress into a take-it-or-leave-it situation is that some of Lighthizer's changes in the new NAFTA agreement might obtain support from the Democrats, even at the expense of some Republicans. These changes included strengthening the labor language in NAFTA to increase wages in Mexico and more rules to protect domestic industries (Behsudi and Restuccia, 2018).

Another epistemic community is the CRS, which comprises M. Angeles Villarreal and Ian F. Fergusson, who are experts in international trade and finance. These two experts created a CRS report for Congress concerning the analysis of the renegotiation of NAFTA proposed by President Trump. The report was considered by Congress before approving Trump's proposal to renegotiate NAFTA. In that report, the trade balance with NAFTA member had fluctuated since the agreement was implemented: It increased from US\$9.1 billion in 1993 to US\$139.0 billion in 2008 and then decreased to US\$75.3 billion in 2016. This report supports that NAFTA renegotiation is an appropriate action.

The Business Advisory Council also influenced the learning process of NAFTA renegotiation. This Council comprises CEOs of companies in various fields in the United States. This strategic policy forum in the field of business economics was established in February 2017, under an initiative from President Trump. This council comprises business experts in their respective fields and is provided a forum to convey their aspirations to the President and Congress. Chaired by Blackstone CEO Stephen Schwarzman, who recruited the advisory committee's members, this council aims to provide recommendations in NAFTA Consultations, including meetings between US Trade Representatives and members of the House Ways and Means Committee and Senate Finance Committee.

\section{CONCLUSION}

International regime theory provides approaches that can be used to understand state behavior in the context of the international regime's order. One approach is the cognitive school of thought with a weak cognitivist approach. Its main assumption is that state behavior in an international regime is closely related to the ideas and knowledge of the state, the learning process of the state in the regime, and the role of epistemic communities. These three considerations are used as an analytical tool to elaborate on the influencing factors of the United States' renegotiation of NAFTA under President Trump.

Using such knowledge-based or idea-based theory, the author found a change in the process of developing ideas and knowledge experienced by the United States regarding NAFTA, starting from President Bush's positive perceptions and followed by the slightly positive perceptions of President Obama and President Trump's negative perception. These three eras indicate a significant change in ideas and knowledge from a positive perception to a negative perception. 
The change in ideas and new knowledge proposed by President Trump has become a new perception for the Republican Party of NAFTA. Through the learning process, the new knowledge and ideas were disseminated, and the construction of a new definition of US interests in NAFTA was established. The proposal of ideas and knowledge in the form of NAFTA renegotiation was successfully disseminated to the decision makers until finally approved by Congress. With the approval of Congress, the United States under President Trump prioritized its efforts to renegotiate NAFTA. In the learning process, the role of epistemic communities also influenced the dissemination and acceptance of new ideas and knowledge. The support of epistemic communities, such as Navarro, Lighthizer, the CRS, and the Business Advisory Council, had a significant influence on US policy to renegotiate NAFTA.

To conclude, the US policy, in an attempt to change the existing regime order, regarding NAFTA, this study used the international regime's theoretical framework, namely, a weak cognitivism approach, through understanding the role of ideas and knowledge, learning processes, and the role of epistemic communities behind a state's behavior.

\section{REFERENCES}

[1] Behsudi, A. and Restuccia, A. (2018) 'Lighthizer Favors Hardball Tactic With Congress on NAFTA', Politico, 20 April [online]. Availabe at: https://www.politico.com/story/2018/04/20/lighthiz er-nafta-trump-trade-congress-539248

[2] Breuninger, K. (2018) 'Read Trump's Full Prepared Remarks From His First State of the Union Address', $C N B C, 31$ January [online]. Availabe at: https://www.cnbc.com/2018/01/30/read-trumpsfull-prepared-remarks-from-the-state-of-the-unionaddress.html

[3] Bush, G.W. (2010) Decision points. New York: Crown Publishers.

[4] Dallas News. 2018 'Point Person: Our Q\&A With Former President George W. Bush on NAFTA', The Dallas Morning News. Availabe at: ttps://www.dallasnews.com/opinion/commentary/2 015/10/30/point-person-our-qa-with-formerpresident-george-w.-bush-on-nafta (Accessed: 23 December 2018)

[5] Foreign Trade Information System Organization of American States. Canada-Mexico-United States. Availabe at: http://www.sice.oas.org/tpd/nafta/nafta_e.asp\#Und erstanding (Accessed: 23 December 2018)
[6] Frosch, D. (2016) 'George W. Bush Praises Nafta in Dallas Speech', The Wall Street Journal, 15 November [online]. Availabe at: https://www.wsj.com/articles/george-w-bushpraises-nafta-in-dallas-speech-1479242158

[7] Grunwald, M. (2017) 'The Trade Deal We Just Threw Overboard', Politico Magazine, April/March [online]. Availabe at: https://www.politico.com/magazine/story/2017/03/ trump-tpp-free-trade-deal-obama-renegotiate-nafta214874.

[8] Hasenclever, A., Mayer, P. and Rittberger, V. (1997) Theories of international regimes. Cambridge: Cambridge University Press.

[9] Jagannathan, M. (2017) 'Here Are All The Terrible Things President Trump Has Said About NAFTA-Before Deciding To Stick With It', New York Daily News, 27 April [online]. Availabe at: http://www.nydailynews.com/news/politics/terrible -president-trump-nafta-article-1.3107104 (Accessed: 9 June 2017)

[10] Keohane, R. (1982) 'The demand for international regimes', International Organization', 36(2), p325$355 . \quad$ Available at: http://www.jstor.org/stable/2706525

[11] Lowrey, A. (2018) 'The "Madman" Behind Trump's Trade Theory', The Atlantic, December [online]. Available at: https://www.theatlantic.com/magazine/archive/201 8/12/peter-navarro-trump-trade/573913/

[12] Morrow, A., Curry, B. et. al. (2018) 'The Road To A New NAFTA: A Recap', The Globe And Mail, 27 April [online]. Available at: https://www.theglobeandmail.com/politics/articlethe-road-to-a-new-nafta-a-recap/

[13] Payne, W.S. (2017) North American Free Trade Agreement: An Overview. Washington DC: Bipartisan Policy Center.

[14] Quora Contributor. (2016) 'President Obama Explains the Difference between TPP and NAFTA in Layman's Terms', Forbes, 28 October [online]. Available at: https://www.forbes.com/sites/quora/2016/10/28/pre sident-obama-explains-the-difference-between-tppand-nafta-in-laymans-terms/\#700e0c5e12eb

[15] Rowlands, I.H. (1991) Ozone Layer Depletion and Global Warming, Peace and Change. Wiley Online Library.

[16] Talbott, J.R. (2008) Obamanomics: How BottomUp Economic Prosperity Will Replace Trickle- 
Down Economics Paperback. New York: Seven Stories Press.

[17] Trump, D.J. (2011) Time to Get Tough: Making America \#1 Again. Massachusets: Regnery Publishing.

[18] Trump, D.J. (2016) Donald J. Trump Foreign Policy Speech. Available at: https://www.donaldjtrump.com/press- releases/donaldj.-trump-foreign-policy speech?_e_pi_=7\%2CPAGE_ID10\%2C109316983 0 (Accessed: 9 June 2018)

[19] Villarreal, M.A. and Fergusson, I.F. (2018) NAFTA Renegotiation and Modernization. Congressional Research Service. Available at: https://fas.org/sgp/crs/row/R44 